\title{
Dysregulation of Microtubule Nucleating Proteins in Cancer Cells
}

\author{
Pavel Dráber *(D) and Eduarda Dráberová
}

Citation: Dráber, P.; Dráberová, E. Dysregulation of Microtubule Nucleating Proteins in Cancer Cells. Cancers 2021, 13, 5638. https:// doi.org/10.3390/cancers13225638

Academic Editors: Nina-Naomi Kreis and Andreas Ritter

Received: 11 October 2021

Accepted: 8 November 2021

Published: 11 November 2021

Publisher's Note: MDPI stays neutral with regard to jurisdictional claims in published maps and institutional affiliations.

Copyright: (c) 2021 by the authors. Licensee MDPI, Basel, Switzerland. This article is an open access article distributed under the terms and conditions of the Creative Commons Attribution (CC BY) license (https:// creativecommons.org/licenses/by/ $4.0 /)$.
Department of Biology of Cytoskeleton, Institute of Molecular Genetics, Czech Academy of Sciences, CZ-142 20 Prague, Czech Republic; drabere@img.cas.cz

* Correspondence: paveldra@img.cas.cz; Tel.: +420-241-062-632

Simple Summary: The dysfunction of microtubule nucleation in cancer cells changes the overall cytoskeleton organization and cellular physiology. This review focuses on the dysregulation of the $\gamma$-tubulin ring complex $(\gamma$-TuRC) proteins that are essential for microtubule nucleation. Recent research on the high-resolution structure of $\gamma$-TuRC has brought new insight into the microtubule nucleation mechanism. We discuss the effect of $\gamma$-TuRC protein overexpression on cancer cell behavior and new drugs directed to $\gamma$-tubulin that may offer a viable alternative to microtubule-targeting agents currently used in cancer chemotherapy.

Abstract: In cells, microtubules typically nucleate from microtubule organizing centers, such as centrosomes. $\gamma$-Tubulin, which forms multiprotein complexes, is essential for nucleation. The $\gamma$-tubulin ring complex $(\gamma$-TuRC) is an efficient microtubule nucleator that requires additional centrosomal proteins for its activation and targeting. Evidence suggests that there is a dysfunction of centrosomal microtubule nucleation in cancer cells. Despite decades of molecular analysis of $\gamma$-TuRC and its interacting factors, the mechanisms of microtubule nucleation in normal and cancer cells remains obscure. Here, we review recent work on the high-resolution structure of $\gamma$-TuRC, which brings new insight into the mechanism of microtubule nucleation. We discuss the effects of $\gamma$-TuRC protein dysregulation on cancer cell behavior and new compounds targeting $\gamma$-tubulin. Drugs inhibiting $\gamma$-TuRC functions could represent an alternative to microtubule targeting agents in cancer chemotherapy.

Keywords: cancers; microtubule nucleation; $\gamma$-tubulin complexes

\section{Introduction}

Microtubules are cytoskeletal polymers that are indispensable for vital cellular activities, such as cell division, migration, maintenance of cell shape, and ordered vesicle transport powered by motor proteins. They are also essential in organizing the spatial distribution of cellular organelles and signal transduction. Microtubules are intrinsically dynamic, as they oscillate stochastically between periods of growth and depolymerization in a process known as "dynamic instability of microtubules" [1]. Microtubules are assembled from globular $\alpha \beta$-tubulin heterodimers in a GTP-dependent manner to form a cylinder with an outer diameter of approximately $25 \mathrm{~nm}$. The $\alpha \beta$-tubulin heterodimers are non-covalently joined in a head-to-tail fashion to form a linear protofilament. Thirteen parallel polar protofilaments associate laterally to form a left-handed helical microtubule wall. Microtubules are thus inherently polar and contain two structurally different ends: a slow-growing minus $(-)$ end and a fast-growing plus $(+)$ end. $\alpha$-Tubulin is oriented toward the $(-)$ end, while $\beta$-tubulin is oriented toward the $(+)$ end of the microtubule [2]. Both the $\alpha$ - and $\beta$-tubulin subunits bind GTP; however, only the nucleotide on $\beta$-tubulin is hydrolyzed. GTP-bound tubulin dimers are incorporated into growing microtubules. GTP hydrolysis occurs with a delay after a GTP-tubulin dimer incorporates into the sheet-like structure of the growing microtubule tip. The growing microtubule ends thus maintain 
stabilizing GTP cap, the loss of which leads to rapid depolymerization [3]. In cells, microtubules are usually anchored to microtubule organizing centers (MTOCs) by their $(-)$ ends, whereas the non-anchored $(+)$ ends are highly dynamic. The dynamic properties of microtubules help to facilitate the remodeling of the microtubule network in response to internal or external signals. Although the structure of microtubules is conserved among various cell types, it can be adapted to highly divergent tasks by mechanisms that are still not fully understood. The incorporation of alternative tubulin isotypes, post-translational modifications (PTMs) of tubulin subunits, and interaction with microtubule-associated proteins (MAPs) regulate the microtubule properties. Intracellular microtubule organization is further controlled by the distribution of nucleation sites and proteins regulating microtubule organization [4].

Centrosomes, composed of two barrel-shaped and orthogonally arranged microtubulebased centrioles wrapped in a multiprotein matrix termed pericentriolar material (PCM), represent major MTOCs for nucleating microtubules in mammalian cells (Figure 1). Numerous scaffold and effector proteins, kinases, and phosphatases are involved in the formation of PCM-ordered layers and the organization of microtubules [5,6]. Centrosomes serve as hubs for the integration and coordination of various signaling pathways [7] and participate in actin filament organization [8,9]. Microtubule nucleation can also take place in other MTOC locations, such as the Golgi apparatus, nuclear envelope, plasma-membrane associated sites, pre-existing microtubules, and chromatin. These non-centrosomal sites play a significant role in the architecture of the microtubule network. $\gamma$-Tubulin, together with other proteins, named $\gamma$-tubulin complex proteins (GCPs), assembles into $\gamma$-tubulin ring complexes $(\gamma$-TuRCs), which represent the essential components for microtubule nucleation in various cellular locations [10-13].

In healthy cells, centrosome duplication ensures the formation of two functional centrosomes, which assemble bipolar spindles to avoid chromosomal aberrations in mitosis. By contrast, many cancer cells harbor extra centrosomes [14]. Centrosome amplification or its structural aberrations represent a hallmark of human cancers with direct consequences for chromosomal instability and can trigger cellular invasion $[15,16]$. Numerous studies have correlated the presence and the degree of centrosome amplification with indicators of poor prognoses, such as higher tumor grade and ability to recur and metastasize $[17,18]$.
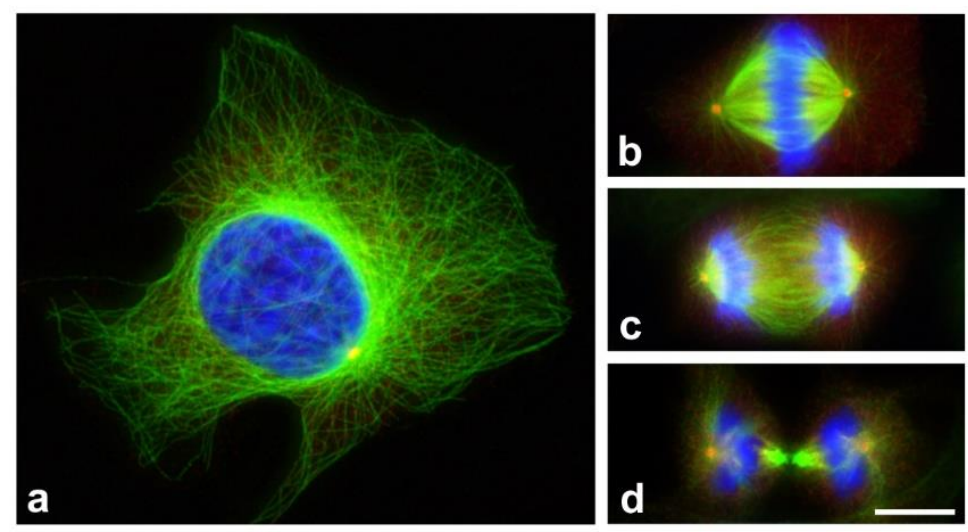

Figure 1. Microtubule nucleation during the cell cycle. Microtubules nucleated from centrosomes undergo substantial reorganization throughout the cell cycle. Human osteosarcoma U2OS cells in interphase (a), metaphase (b), anaphase (c), and late telophase (d) stained for microtubules with polyclonal anti- $\alpha$-tubulin antibody (Genetex, GTX 15246; green) and for centrosomes with monoclonal anti- $\gamma$-tubulin antibody TU-30 [19] (red). DNA in blue. Formaldehyde-fixed samples were extracted with Triton X-100 and postfixed in methanol. Scale bar, $10 \mu \mathrm{m}$.

This review will focus on the latest research and emerging questions concerning centrosomal microtubule nucleation. Specific attention will be given to the high-resolution structure of $\gamma$-TuRC, dysregulation of $\gamma$-TuRC building proteins in cancer cells, and to new drugs targeting $\gamma$-tubulin functions. 


\section{Microtubules as Targets in Cancer Chemotherapy}

Multiple genes encode both $\alpha$-tubulin and $\beta$-tubulin isotypes, which differ in amino acid sequences mainly in their C-terminal ends. The C-terminal amino acids form unstructured tails that protrude from the microtubule surface. Differences among isotypes are often highly conserved in evolution, suggesting that they have functional significance [20]. Humans have nine isotypes for both $\alpha$ - and $\beta$-tubulin. Certain isotypes are ubiquitous, while others have cell- or tissue-specific expression and are important for the function of specialized microtubule arrays [21,22]. The amino acid sequences of tubulin isotypes incorporated into a microtubule and the PTMs on tubulin molecules generate the so-called tubulin code, which can lead to differences in microtubule properties. Wellcharacterized PTMs include acetylation, detyrosination, tyrosination, (poly)glutamylation, and (poly)glycylation. Additionally, there are many other PTMs, such as phosphorylation, methylation, polyamination, palmitoylation, arginylation, glycosylation, nitration, ubiquitylation, and sumoylation [23,24]. PTMs of tubulin isotypes result in multiple tubulin charge variants, or tubulin isoforms, which can be discriminated by high-resolution isoelectric focusing $[25,26]$. The tubulin code precisely controls microtubule properties and interactions of microtubules with a large number of MAPs. These can be divided into microtubule-stabilizing MAPs, microtubule-severing proteins, microtubule cross-linking proteins, and microtubule-assembly and disassembly promoters [4,27]. For example, acetylation makes microtubules more resistant to mechanical bending-induced breakage [28], and polyglutamylation regulates spastin-mediated microtubule severing [29].

Vertebrate $\beta$-tubulin isotypes have fairly distinct tissue distributions [30]. Compared with other $\beta$-tubulin isotypes, $\beta$ III-tubulin possesses distinctive biochemical properties [31]. Despite its restricted and predominantly neuronal cell-type distribution in normal tissues, the $\beta \mathrm{III}$ isotype is expressed in a broad range of human tumors of neuronal and nonneuronal origin. At present, there is a general agreement that abnormal overexpression of $\beta I I I-t u b u l i n$ in non-neuronal cancers is associated with an overall proclivity for aggressive tumor behavior and poor patient outcome [32].

Microtubule targeting agents (MTAs) are essential drug classes for cancer chemotherapy. Cancerous cells are characterized by, amongst other things, their potential to undergo continuous rounds of mitotic cell division. MTAs alter microtubule dynamics and interfere with the formation of the mitotic spindle. Errors in mitotic spindle function stimulate the spindle assembly checkpoint to block mitotic progression until all chromosomes are correctly attached by microtubules [33]. The long-term blocking of bipolar spindle formation by MTAs can eventually lead to apoptotic death, which is a strategy to combat cancer [34]. According to their effects on microtubules at high concentrations, MTAs are grouped into microtubule-stabilizing agents (MSAs) and microtubule destabilizing agents (MDAs). However, at low and clinically relevant concentrations, both MSAs and MDAs suppress microtubule dynamics without significantly affecting the amount of polymerized tubulin [35]. There are six known MTA binding sites identified on the tubulin dimer. The MSAs bind to taxane and laulimalide/peloruside sites, while MDAs bind to vinca, maytansine, colchicine, and pironetin sites. Except for the pironetin site, which is on $\alpha$-tubulin, the other sites are located on $\beta$-tubulin [36]. The only MTAs approved by the Food and Drug Administration so far are those that bind to sites on $\beta$-tubulin.

The effectiveness of MTAs for cancer therapy is limited by their side effects and cancer cell drug resistance. The primary side effects are neurological and hematological and often limit the dose that can be administered, but several other side effects also occur during treatment with each individual drug [37]. Cancer cells also acquire resistance to MTAs through multiple mechanisms: (1) decreased cellular drug accumulation owing to the overexpression of membrane-bound drug efflux proteins, such as multidrug resistanceassociated protein 1 and P-glycoprotein; (2) $\beta$-tubulin mutations at the drug binding sites; (3) altered expression of tubulin isotypes or MAPs; (4) changes to the microtubule dynamics induced by interactions with other cytoskeletal proteins; and (5) defects in apoptotic 
pathways [30]. Of the tubulin alterations, the increased abundance of $\beta$ III-tubulin is the most prevalent mechanism associated with the resistance to MTAs in patients [38].

\section{3. $\gamma$-Tubulin and Microtubule Nucleation by $\gamma$-Tubulin Complexes}

One of the key components required for microtubule nucleation and stabilization is $\gamma$-tubulin [39], a highly conserved albeit less abundant member of the tubulin superfamily. $\gamma$-Tubulin represents $<1 \%$ of the total tubulin content in the cell [40]. In contrast to $\alpha$ - and $\beta$-tubulins, only two functional $\gamma$-tubulin genes (TUBG1 and TUBG2) exist in humans, encoding two $\gamma$-tubulin isotypes. They are located on the 17th chromosome in tandem, and their coding sequences exhibit $94 \%$ sequence similarity. Although at the protein level, human $\gamma$-tubulin-1 and $\gamma$-tubulin-2 differ by only ten amino acids, they can be discriminated according to their electrophoretic and immunochemical properties [41,42]. Whereas $\gamma$-tubulin- 1 is expressed ubiquitously, $\gamma$-tubulin- 2 is primarily expressed in the brain $[43,44]$. Both $\gamma$-tubulins are nucleation competent [45]. $\gamma$-Tubulin binds GTP, which regulates its nucleation activity [46]. Mammalian $\gamma$-tubulins are phosphorylated at multiple sites [47], and protein kinases and phosphatases were repeatedly identified in $\gamma$-tubulin immunocomplexes, suggesting that phosphorylation might be involved in the regulation of $\gamma$-tubulin interactions [12]. Monoubiquitination of $\gamma$-tubulin inhibits microtubule nucleation [48], and $\gamma$-tubulin ubiquitination plays an important role in the degradation of $\gamma$-tubulin complexes [49].

$\gamma$-Tubulin, together with GCP2-6, forms a 2.2-MDa $\gamma$-TuRC, which catalyzes microtubule nucleation in human cells, providing a structural template that mimics the microtubule geometry [50-52]. GCP2-6 each bind directly to $\gamma$-tubulin and assembles into a cone-shaped structure that templates microtubule assembly by binding $\alpha \beta$-tubulin dimers, and promoting their lateral interactions [53]. Two short homologous regions with low levels of sequence identity, the N-terminal GRIP ( $\gamma$-tubulin ring protein) 1 domain and C-terminal GRIP2 domain, are unique to the GCPs. The GRIP domains are flexibly connected, allowing conformational rearrangement of $\gamma$-tubulins in the complex. $\gamma$-Tubulin interacts with GRIP2 domains, while GRIP1 domains create the primary interface between GCPs $[53,54]$. Recent high-resolution structural studies revealed details of the $\gamma$-TuRC structure [55-58]. In $\gamma$-TuRC, which has a width of $\sim 30 \mathrm{~nm}$ and a height of $\sim 25 \mathrm{~nm}, 14 \gamma$-tubulin molecules are exposed at the open face of the cone and form a left-handed helix with a partial overlap of positions 1 and 14. The luminal bridge, a structural scaffold that lines the interior of the complex, is formed by two molecules of MZT (small mitotic spindle organizing protein) 1 , while the protein MZT2 is located at the outer perimeter of $\gamma$-TuRC [59]. Surprisingly, actin was also shown to be an integral part of this internal structural scaffold. Actin binds with a high affinity to DNAseI. The treatment of purified $\gamma$-TuRC with DNaseI significantly inhibited their microtubule nucleation activity in vitro, and the pre-incubation of DNaseI with actin abolished this effect. Thus, actin is a bona fide structural component of $\gamma$-TuRC and has functional relevance in microtubule nucleation [56]. It appears that actin and associated luminal factors, together with MZT2, are jointly engaged in stabilizing the $\gamma$-TuRC spiral [55]. The structure and molecular architecture of the vertebrate $\gamma$-TuRC are shown in Figure 2. The configuration of $\gamma$-tubulins at the microtubule nucleation interface does not perfectly match the 13-fold symmetry of a microtubule. Spokes 1-8 in $\gamma$-TuRC, containing four GCP(2-3) units, termed $\gamma$-tubulin small complexes $(\gamma$-TuSC), follow microtubule symmetry. On the other hand, spokes 9-14, containing GCP4-6, introduce asymmetry in both the diameter and pitch of $\gamma$-TuRC and are not compatible with microtubule symmetry [60]. This may explain why cytosolic $\gamma$-TuRC has low nucleation activity [55] and conformational changes in the $\gamma$-TuRC structure are necessary for its activation [61]. Both activating protein factors and PTMs of $\gamma$-TuRC proteins can regulate this activation. 


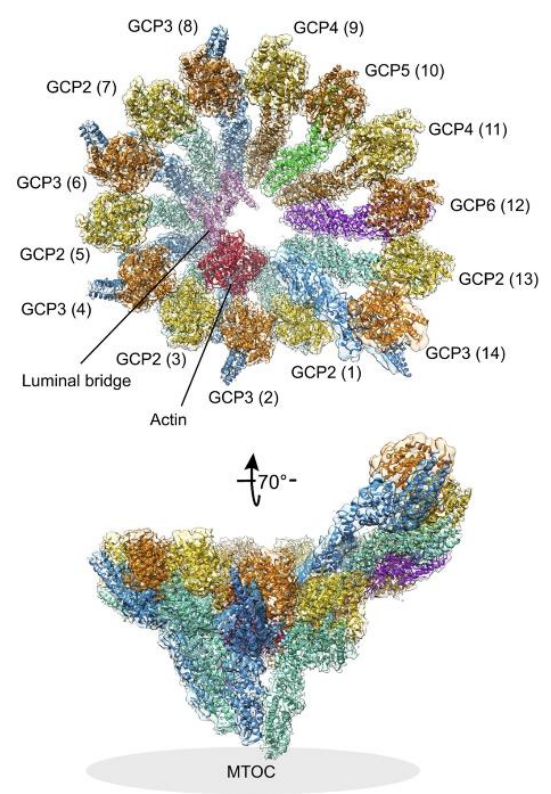

Figure 2. Structure and molecular architecture of the $\gamma$-TuRC. The general architecture of the vertebrate left-handed $\gamma$-TuRC spiral as determined by cryo-EM single-particle analysis. $\gamma$-Tubulins (yellow, orange), GCP2 (aquamarine), GCP3 (blue), GCP4 (brown), GCP5 (green), GCP6 (purple), actin (red), and the luminal bridge (pink) are shown. The spoke numbers are given in brackets. In the tilted view, the approximate location of the MTOC is indicated. (Reprinted by permission from Elsevier: (Curr. Opin. Struct. Biol.; Zupa et al. [60]), copyright (2021).

An important role in the induction of conformational changes is played by the activating factors CDK5RAP2 (cyclin-dependent kinase 5 regulatory subunit-associated protein 2) through its CM1 (centrosomin motif 1) domain [62] and NME7 (nucleoside diphosphate kinase 7) [63]. As $\gamma$-tubulin and GCPs are phosphorylated, their phosphorylation can modulate conformational changes that might be required for $\gamma$-TuRC activation [61]. Various associated proteins are additionally involved in the regulation of centrosomal microtubule nucleation. Targeting and anchoring proteins are not essential for the complex assembly but target $\gamma$-TuRCs to centrosomes and affect their recruitment. CDK5RAP2 is targeted to the centrosome through its CM2 (centrosomin motif 2) domain [64]. Once at the centrosome, the CM1 domain of CDK5RAP2 tethers the $\gamma$-TuRC. Sequential phosphorylation of NEDD1 (neural precursor cell-expressed developmentally down-regulated protein 1) [65] by Cdk1 and Plk1 kinases is required for targeting $\gamma$-TuRC to the centrosome [66]. Anchoring proteins AKAP9 (A-kinase anchor protein 9) [67], pericentrin [68], ninein [69], and Cep192 (centrosomal protein 192) [70] are also important for the localization of $\gamma$-TuRC to centrosomes. However, as these proteins are incorporated in PCM, they can also indirectly affect $\gamma$-TuRC binding. Additionally, modulating proteins are likewise vital for the regulation of centrosomal microtubule nucleation [12]. For example, TACC3 (transforming acidic coiledcoil-containing protein 3) has been found to stabilize $\gamma$-TuRC assembly from $\gamma$-TuSC [71,72]. The building components of $\gamma$-TuRC and its regulating proteins (activating, targeting, and anchoring) in the interphase centrosomes are summarized in Table 1. Proteins interacting with $\gamma$-TuRC can generate a heterogenous population of $\gamma$-TuRCs, which influences the recruitment of $\gamma$-TuRCs to MTOCs [73]. Although $\gamma$-TuRC is widely regarded as a bona fide PCM component nucleating microtubules, it also associates with the outer and inner walls of centriole and centriolar subdistal appendages [74]. 
Table 1. Building components of $\gamma$-TuRC and regulatory proteins of centrosomal microtubule nucleation in interphase cells.

\begin{tabular}{cccc}
\hline $\boldsymbol{\gamma}$-TuRC Proteins & Activating Proteins & Targeting Proteins & Anchoring Proteins \\
\hline$\gamma$-tubulin & CDK5RAP2 & CDK5RAP2 & AKAP9 \\
GCP2 & NME7 & NEDD1 & Cep192 \\
GCP3 & & & Ninein \\
GCP4 & & \\
GCP5 & & \\
GCP6 & & \\
MZT1 & & \\
MZT2 & & \\
Actin & & \\
\hline Protein classification based on recent reviews $[12,60]$. & & \\
\hline
\end{tabular}

It is increasingly evident that $\gamma$-tubulin has functions beyond microtubule nucleation. There have been repeated reports that mutations or deficiencies in $\gamma$-tubulin or GCPs alter (+)-end microtubule dynamics [75]. A microtubule nucleation-independent role of $\gamma$-tubulin complexes was also described for the control of the spindle assembly checkpoint (SAC) and mitotic exit [76] as well as for cell cycle progression in interphase [77]. There are also indications that nuclear $\gamma$-tubulin [78] modulates the activity of E2F transcription factors, which control cell cycle progression $[79,80]$. Although the functional significance is not yet clear, $\gamma$-tubulin associates with proteins involved in DNA damage checkpoints and DNA repair, such as Rad51 [81], BRCA1 [82], CDK5RAP3 [78], and ATR [83]. $\gamma$-Tubulin has an intrinsic property of generating oligomers in vitro [84] and was reported to be capable of forming fine fibers in cells $[85,86]$. The function of such fibrillar structures is unknown. It was suggested that they could serve scaffolding or sequestration functions and might also be involved in mechanotransduction, as they interact with the LINC (linker of the nucleoskeleton and cytoskeleton) complex $[87,88] . \gamma$-Tubulin has also been found in vesicles [89], recycling endosomes [90], and mitochondria [41,86].

\section{Dysregulation of $\gamma$-Tubulin in Cancer Cells}

Analysis of $\gamma$-tubulin expression in clinical tissue samples and cancer cell lines revealed the misregulation of this tubulin isotype, similar to the case of $\beta$ III-tubulin [91]. Multiple studies were performed on brain tumors and breast cancer, but changes in the $\gamma$-tubulin content were also reported in other cancers, as documented below.

Gliomas are the most prevalent group of central nervous system neoplasms, accounting for more than $70 \%$ of all brain tumors [92]. Gliomas are broadly classified as low-grade and high-grade gliomas. Glioblastoma multiforme (GBM) is the most malignant as well as the deadliest glioma and is refractory to currently available treatments. Oligonucleotide microarray analysis revealed that TUBG1 transcripts were increased in GBM when compared with low-grade gliomas [93]. The immunohistochemical reactivity of $\gamma$-tubulin was significantly enhanced in high-grade anaplastic astrocytomas and GBM compared with low-grade diffuse astrocytomas [94]. Robust immunofluorescence staining was also found in glioblastoma cell lines (U87MG, U118MG, U138MG, and T98G). In contrast to pericentrin, which localized to centrosomes, $\gamma$-tubulin was found both on centrosomes and in the cytosol. Moreover, $\gamma$-tubulin localization in nuclei and nucleoli was clearly seen after acetic alcohol fixation [78]. A comparison of $\gamma$-tubulin expression and distribution in the primary culture of normal human astrocytes (NHA) and the human glioblastoma cell line T98G is shown in Figure 3. Interestingly, $\gamma$-tubulin clearly co-distributed with $\beta I I I-t u b u l i n$ in GBM, while co-localization of both tubulins in low-grade gliomas was less evident. Both tubulins formed complexes in cytoplasmic pools from T98G cells [95]. mRNA levels for most centrosomal structural proteins and Aurora kinases were elevated in gliomas compared with normal human brain tissue. Significant differential expression between high- and low-grade gliomas was, however, detected only for $\gamma$-tubulin and Aurora A mRNAs, and upregulation of $\gamma$-tubulin was correlated with tumor grade [96,97]. 
Comparison of $\gamma$-tubulin expression at the transcript and protein level in glioblastoma cell lines and normal human astrocytes (NHA) confirmed enhanced expression of both $\gamma$-tubulin 1 and $\gamma$-tubulin 2 in glioblastoma cell lines U118MG, U138MG, and T98G [78]. These findings were further extended in the study, showing that the expression levels of $\gamma$-tubulin or Aurora A kinase were associated with patients' age, astrocytoma grade, and patient survival and performance [98]. These results suggested that the aberrant expression of both $\beta$ III-tubulin and $\gamma$-tubulin may be linked to malignant changes in glial cells. This could be clinically useful for glioma staging and the development of novel treatment strategies [34]. Enhanced expression of $\gamma$-tubulin in brain tumors is not limited to gliomas. Overexpression of $\gamma$-tubulin was also reported in medulloblastomas and the medulloblastoma cell line D283Med. Overexpression of $\gamma$-tubulin was widespread in poorly differentiated, proliferating tumor cells stained for PCNA (proliferating cell nuclear antigen) but was significantly diminished in quiescent differentiating tumor cells undergoing neuritogenesis. Overexpression of $\gamma$-tubulin in the context of medulloblastomas may be a molecular signature of phenotypic dedifferentiation (anaplasia) and may be linked to tumor progression and worse clinical outcomes [99].
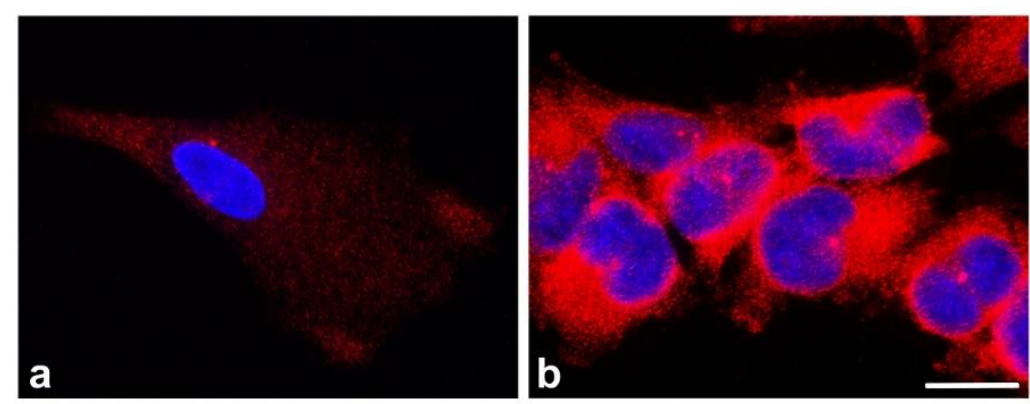

Figure 3. Differential expression and localization of $\gamma$-tubulin in human astrocytes and glioblastoma cells. Comparison of $\gamma$-tubulin distribution (red) in primary culture of human astrocytes (Lonza CC-2565) (a) and human glioblastoma cell line T98G (b) using monoclonal antibody TU-30 [19]. Nuclei in blue. Note the abnormal accumulation of $\gamma$-tubulin outside centrosomes in glioblastoma cells. Fluorescence images were captured and processed in precisely the same manner. Formaldehyde-fixed samples were extracted with Triton X-100 and postfixed in methanol. Scale bar, $20 \mu \mathrm{m}$.

Breast cancer is the most frequent malignancy in women worldwide and is curable in $\sim 70-80 \%$ of patients with early-stage, non-metastatic disease. Advanced breast cancer with distant organ metastases is considered incurable with currently available therapies [100]. Analysis of an extensive series of breast premalignant lesions and carcinoma revealed $\gamma$-tubulin gene amplification and concomitant protein overexpression in a significant fraction of atypical hyperplasia, in situ carcinomas, and invasive carcinomas [101,102]. In a panel of human breast cancer cell lines, prominent cytosolic and nuclear $\gamma$-tubulin immunostaining was found in aggressive breast cancer cell lines. By contrast, $\gamma$-tubulin localization remained largely centrosomal in non-tumorigenic cell lines. It was suggested that changes in $\gamma$-tubulin solubility are regulated on the PTM level [103]. An essential role in regulating microtubule nucleation in breast cancer is played by $\gamma$-tubulin ubiquitylation by the BRCA1 (breast cancer type 1 susceptibility protein)/BARD1 (BRCA1-associated RING domain protein 1) E3 ligase complex. The ubiquitination of $\gamma$-tubulin results in its detachment from the centrosome and inhibition of microtubule nucleation. The loss of the BRCA1 protein, as occurs in many breast cancers, induces centrosome amplification and enhances the formation of large microtubule asters from centrosomes [48,104,105]. A significant role in the regulation of breast cancer centrosomes is also played by deubiquitylase BAP1 (BRCA1-associated protein-1). The removal of ubiquitin from $\gamma$-tubulin by BAP1 induces the recruitment of unmodified $\gamma$-tubulin to the centrosome during mitosis [106].

Elevated expression of $\gamma$-tubulin was reported in a large cohort of clinical tissue samples from non-small cell lung cancer (NSCLC). While in the non-neoplastic cells of the airway epithelium in situ, $\gamma$-tubulin exhibited predominantly apical surface and pericentri- 
olar localizations, markedly increased cytosolic $\gamma$-tubulin immunoreactivity was detected in clinical tumor specimens. A notable increase of $\gamma$-tubulin expression was found in stage III compared with lower-stage tumors (stages I/II). Increased $\gamma$-tubulin expression was also found in NSCLC tumor cell lines NCI-H460 and NCI-H69 compared with small airway epithelial cells (SAEC) $[107,108]$. Additionally, increased $\gamma$-tubulin expression was reported in surgically resected laryngeal carcinomas [109], thyroid carcinomas [110], ovarian cancer [111], and prostate cancer cells [112].

The increased expression of $\gamma$-tubulin in some cancer types may be linked to increased microtubule nucleating capacity through conventional or supernumerary centrosomes, which could result in enhanced invasiveness [113]. The increased level of $\gamma$-tubulin might also be connected to abnormal centrosomal functions due to the structural changes in centrioles [16]. Moreover, non-centrosomal microtubule nucleation could also be affected. As $\gamma$-tubulin has functions beyond microtubule nucleation, its overexpression can change microtubule (+)-end dynamics [75] as well as intracellular signaling pathways because $\gamma$-tubulin interacts with various protein kinases [12]. Dysregulation of $\gamma$-tubulin in cancer cells can also modulate cell cycle [77], transcription [79,80], DNA damage checkpoint [78], and DNA repair $[81,83]$.

\section{Dysregulation of the Other $\gamma$-TuRC Building Components}

Contrary to $\gamma$-tubulin, data on changes in the expression of GCPs in cancer cells are limited, and dysregulation was reported only for GCP2 and GCP3 [114]. In accordance with increased expression of $\gamma$-tubulin in glioma cells, the expression of GCP2/GCP3 was augmented both at the transcript and protein level in U87MG, U118MG, U138MG, T98G, and KNS glioma cell lines compared with NHA. Both proteins were concentrated on the centrosomes of interphase cells, but they were also located in the cytosol and nuclei/nucleoli. GCP2 and GCP3 were found in complexes with $\gamma$-tubulin in the nucleoli, as confirmed by reciprocal immunoprecipitation experiments and immunoelectron microscopy. GCP2 and GCP3 depletion caused the accumulation of cells in G2/M and mitotic delay but did not affect nucleolar integrity. Similarly, as in the case of $\gamma$-tubulin overexpression [78], the enhanced level of GCP2 antagonized the inhibitory effect of the CDK5RAP3 (cyclin-dependent kinase 5 regulatory subunit-associated protein 3) on DNA damage G2/M checkpoint activity. The immunohistochemical reactivity for $\gamma$-tubulin was significantly enhanced in GBM compared with low-grade diffuse gliomas. These findings suggest that $\gamma$-TuSC protein dysregulation in glioblastomas may be linked to altered transcriptional checkpoint activity or interaction with signaling pathways associated with a malignant phenotype [114]. GCP2 was shown to be upregulated at the transcript level in the taxol-resistant ovarian cancer cell line SKOV3 and was described to be associated with sensitization of the NSCLC cell line NCI-H1155 to taxol [115].

Concerning MZT proteins, which are integral parts of $\gamma$-TuRCs, increased expression was recently reported for MZT2A in NSCLC. Both MZT2A mRNA and protein were upregulated in NSCLC tissues, which correlated with larger NSCLC size, lymph node metastasis, and poor NSCLC prognosis. MZT2A was highly expressed in all tested NSCLC cell lines except for NCI-H460 compared with normal bronchial cells. MZT2A overexpression promoted NSCLC cell viability and invasion. Moreover, MZT2A indirectly induced Akt phosphorylation to promote NSCLC proliferation and invasion [116].

Actin plays essential roles in aberrant processes in cancer, including signaling, morphology, motility, and division. As actin has functional relevance in microtubule nucleation [56], changes in the actin level in cancer cell types might also affect microtubule nucleation. Mass spectrometry analysis suggested that preferentially $\beta$ - or $\gamma$-actin is integrated into $\gamma$-TuRC, but the nearly identical sequences between actin isoforms indicate that the isotype of $\gamma$-TuRC-associated actin may depend on the expression profiles in particular cells [117]. The upregulation of $\beta$-actin or $\gamma$-actin was reported in many cancers [118]. Moreover, $\gamma$-actin was shown to be involved in the regulation of centrosome function and mitotic progression in cancer cells [119]. Interestingly, profilin 1, a principal control 
component of actin polymerization, also modulates microtubule dynamics [120,121]. It was reported recently that profilin 1 interacts with $\gamma$-TuRCs and attenuates centrosomal microtubule nucleation [122]. Profilin has multiple isoforms, and it has been shown that the ratio of profilin 1 to profilin 2 transcripts in primary tumors decreases. Elevated levels of profilin 1 correlated with tumor-suppressive effects [123]. It was proposed that in the moving cells, profilin 1 and profilin 1 -actin are recruited to the advancing cell edge to support upregulation of actin turnover and the formation of lamellipodia. Consequently, profilin concentration at the centrosome is lowered, which causes increased nucleation of microtubules from the centrosome [124]. Accordingly, profilin 1 might modulate both cell motility and centrosomal microtubule nucleation in highly invasive cancer cells.

\section{Therapeutic Potential of $\gamma$-Tubulin Targeting}

The clinical usefulness of many MTAs has been hampered by cancer cell drug resistance. Several studies have suggested that $\gamma$-tubulin might be a good candidate for the development of new anticancer drugs. First, $\gamma$-tubulin accumulates on the centrosome at the onset of mitosis to facilitate bipolar spindle assembly [125]. Second, elevated microtubule nucleation from amplified centrosomes enhances the invasiveness of tumor cells [15]. Third, centrosomal microtubule nucleation has been shown to be an attractive drug target $[126,127]$. Finally, $\gamma$-tubulin is overexpressed in different cancers, as presented in Section 4 of this review. Reversing the high nucleation capacity of centrosomes through $\gamma$-tubulin inhibition may reduce the aggressiveness and metastatic potential of the wide range of cancer cells with supernumerary centrosomes.

It was reported that colchicine and combretastatin $\mathrm{A}$, which bind to colchicine binding site on $\beta$-tubulin, also associate with recombinant human $\gamma$-tubulin 1 [128]. Because $\gamma$-tubulin is structurally quite similar to $\beta$-tubulin [129], several laboratories started to develop $\gamma$-tubulin-specific inhibitors from known drugs which bind to a colchicine-binding site on $\beta$-tubulin. This approach identified gatastatin $\left(\mathrm{O}^{7}\right.$-benzyl glaziovianin A derivative $)$ as an inhibitor that had a higher affinity toward $\gamma$-tubulin in comparison with $\alpha \beta$-tubulin. Gatastatin blocked GTP binding to $\gamma$-tubulin, inhibited centrosomal microtubule nucleation, and impaired spindle formation [130]. Molecular docking and molecular dynamics methods revealed the binding of gatastatin to the GTP binding site on $\gamma$-tubulin [131]. However, the cytotoxicity of gatastatin to cancer cells was relatively weak compared with that of conventional MTAs, such as paclitaxel or vinblastine. On the other hand, the cytotoxicity of gatastatin was significantly increased by Plk1 inhibitor BI 2536. Dual inhibition of $\gamma$-tubulin and Plk1 arrested cell cycle progression, generated abnormal spindles, and caused spindle assembly checkpoint-dependent mitotic cell death by impairing centrosome functions. These results raised the possibility of Plk1 and $\gamma$-tubulin inhibitor co-treatment as novel cancer chemotherapy [132]. Further optimization of gatastatin recently led to the preparation of the highly specific $\gamma$-tubulin inhibitor gatastatin $2\left(\mathrm{O}^{6}\right.$-propargyl-gatastain), which showed potent cytotoxicity, induced abnormal spindle formation with misaligned chromosomes, and inhibition of microtubule nucleation [133].

The same approach of chemical modification of known drugs binding to the $\beta$-tubulin colchicine site was used in the case of resveratrol (3,5,4'-trihydroxy-trans-stilbene, a naturally occurring phenol), which binds to the colchicine site and has anti-carcinogenic activity. The synthetic manipulation of the stilbene scaffold of resveratrol led to new analogs with improved anticancer activity and better bioavailability. 3,4,4'-Trimethoxystilbene (3,4,4'-TMS) inhibited cell proliferation, depolymerized the mitotic spindle, and produced a fragmentation of the pericentriolar material. Computer-assisted docking studies showed the interaction of $3,4,4^{\prime}$-TMS with $\gamma$-tubulin [134]. Noscapine (phthalide isoquinoline alkaloid) is a non-addictive opioid with antitumor activity that easily transverses the bloodbrain barrier and does not induce peripheral neuropathy, which is common with other MTAs. It was shown that $9^{\prime}$-bromonoscapine, which has significant anticancer activity, binds at or near the $\beta$-tubulin colchicine site [135]. Molecular docking, molecular dynamics simulation, and binding free energy calculation indicated its binding into a pocket located 
at the binding interface between two adjacent $\gamma$-tubulin molecules [136]. Structurally simplified noscapine analogs that selectively bind only to $\gamma$-tubulin could represent new tools for the treatment of glioblastoma with a high level of $\gamma$-tubulin [137].

Finally, the targeting of nuclear-specific $\gamma$-tubulin function(s) was also reported. $\gamma$-Tubulin and RB1 (retinoblastoma transcriptional corepressor 1) moderate each other's expression by direct binding to sites for E2Fs transcription factors on the TUBG1 and RB1 promoter regions. The RB1 tumor suppressor pathway is well-described, and it is highly mutated in a large spectrum of cancers [138]. In the absence of nuclear $\gamma$-tubulin and RB1, the uncontrolled transcriptional activity of E2Fs upregulates apoptotic genes, causing cell death [139]. It was shown that terpenoid citral dimethyl acetal (CDA) increased E2F activity without affecting microtubules and showed a cytotoxic effect in cells with a nonfunctional RB1 pathway. In silico and in vitro experiments demonstrated that CDA prevents GTP binding to $\gamma$-tubulin. It was proposed that drugs specifically designed to inhibit the nuclear activity of $\gamma$-tubulin could target malignant tumors without affecting healthy cells [140].

\section{Conclusions and Perspectives}

More than 25 years of research on $\gamma$-tubulin complexes led to the conclusion that they are almost universally involved in microtubule nucleation. The $\gamma$-TuRCs have been shown to form microtubule templates, and their attachment to both centrosomal and noncentrosomal sites correlates with an increase in microtubule nucleating activity. The recent structural studies on $\gamma$-TuRC have been highly illustrative, but a central open question for the future will be to understand how the various proteins involved in the regulation of microtubule nucleation control the conformation and activity of $\gamma$-TuRCs. Little is known about the upstream signaling pathways ensuring that these proteins initiate microtubule nucleation at the correct location and time. The importance of centrosomal kinases and phosphatases in the regulation of nucleation is emerging, but the details are only partially understood. A thorough comprehension of microtubule nucleation should clarify the relevance of $\gamma$-TuRC dysregulation in cancer cells.

Understanding the role of $\gamma$-tubulin isotypes in DNA damage checkpoints and signaling pathways to DNA repair will be essential to elucidate the role of $\gamma$-tubulin in tumorigenesis. Although centrosome amplification and increases in $\gamma$-tubulin cell content are present in various human tumors, extensive clinical randomized studies are necessary to further evaluate the predictive value of the $\gamma$-tubulin level in the context of different clinical stages, histological types, tumor grades, and treatment settings. It is also becoming increasingly clear that microtubules and actin filaments work together in core cellular processes, and their dynamic properties are often intertwined. It remains to be determined how the dysregulation of microtubule nucleating and regulatory proteins affects the cross-talk between these two cytoskeletal systems in highly motile aggressive cancer cells.

Currently, the most common and most effective chemotherapy compounds are MTAs that bind microtubules directly. Targeting $\gamma$-TuRCs may offer a viable alternative to perturbing cancer cells. A future challenge will be to develop drugs that can inhibit $\gamma$-TuRC function in a precise manner. The elucidation of the three-dimensional structure of $\gamma$-tubulin and $\gamma$-TuRC has provided an opportunity for rational drug design aimed at generating compounds that will target microtubule nucleation in more therapeutically efficacious ways compared with the presently available MTAs. In this respect, non-essential $\gamma$-TuRC proteins could also represent potential targets for anticancer drugs, as their inhibition may affect only subsets of $\gamma$-TuRCs. 
Author Contributions: P.D. and E.D. conceived and designed the manuscript, collected the relevant references, and wrote and revised the manuscript. E.D. secured immunofluorescence documentation, and P.D. provided funding. All authors have read and agreed to the published version of the manuscript.

Funding: This work was supported in part by grants 19-20716S and 21-30281S from the Czech Science Foundation, LTAUSA19118 from the Ministry of Education, Youth and Sports of the Czech Republic, and by Institutional Research Support (RVO 68378050).

Acknowledgments: We thank Vadym Sulimenko (Institute of Molecular Genetics, Czech Academy of Sciences, Prague, Czech Republic) and Roger Karlsson (Department of Molecular Biosciences, Stockholm University, Sweden) for fruitful discussion during the preparation of this review.

Conflicts of Interest: The authors declare no conflict of interest. The funders had no role in the design of the study; in the collection, analyses, or interpretation of data; in the writing of the manuscript; or in the decision to publish the results.

\section{Abbreviations}

$\begin{array}{ll}\text { AKAP9 } & \text { A-kinase anchor protein } 9 \\ \text { BRCA1 } & \text { breast cancer type } 1 \text { susceptibility protein } \\ \text { CDK5RAP2 } & \text { cyclin-dependent kinase } 5 \text { regulatory subunit-asociated protein } 2 \\ \text { CDK5RAP3 } & \text { cyclin-dependent kinase } 5 \text { regulatory subunit-associated protein } 3 \\ \text { CDA } & \text { citral dimethyl acetal } \\ \text { Cep192 } & \text { centrosomal protein } 192 \\ \text { GBM } & \text { glioblastoma multiforme } \\ \text { GCP } & \gamma \text {-tubulin complex protein } \\ \text { GRIP } & \gamma \text {-tubulin ring protein } \\ \text { MAP } & \text { microtubule-associated protein } \\ \text { MDA } & \text { microtubule destabilizing agent } \\ \text { MTA } & \text { microtubule targeting agent } \\ \text { MTOC } & \text { microtubule organizing center } \\ \text { MSA } & \text { microtubule stabilizing agent } \\ \text { MZT } & \text { mitotic spindle organizing protein } \\ \text { NEDD1 } & \text { neural precursor cell expressed developmentally down-regulated protein } 1 \\ \text { NHA } & \text { normal human astrocytes } \\ \text { NME7 } & \text { nucleoside diphosphate kinase } \\ \text { NSCLC } & \text { non-small cell lung cancer } \\ \text { PCNA } & \text { proliferating cell nuclear antigen } \\ \text { PTM } & \text { post-translational modification } \\ \text { RB1 } & \text { retinoblastoma transcriptional corepressor 1 } \\ \gamma \text {-TuRC } & \gamma \text {-tubulin ring complex } \\ \gamma \text {-TuSC } & \gamma \text {-tubulin small complex }\end{array}$

\section{References}

1. Mitchison, T.; Kirschner, M. Dynamic instability of microtubule growth. Nature 1984, 312, 237-242. [CrossRef]

2. Nogales, E.; Wang, H.W. Structural mechanisms underlying nucleotide-dependent self-assembly of tubulin and its relatives. Curr. Opin. Struct. Biol. 2006, 16, 221-229. [CrossRef] [PubMed]

3. Akhmanova, A.; Steinmetz, M.O. Control of microtubule organization and dynamics: Two ends in the limelight. Nat. Rev. Mol. Cell Biol. 2015, 16, 711-726. [CrossRef] [PubMed]

4. Dráber, P.; Dráberová, E. Microtubules. In Cytoskeleton and Human Disease; Kavallaris, M., Ed.; Humana Press: New York, NY, USA, 2012; pp. 29-54.

5. Woodruff, J.B.; Wueseke, O.; Hyman, A.A. Pericentriolar material structure and dynamics. Philos. Trans. R. Soc. Lond. B Biol. Sci. 2014, 369, 20130459. [CrossRef]

6. Fry, A.M.; Sampson, J.; Shak, C.; Shackleton, S. Recent advances in pericentriolar material organization: Ordered layers and scaffolding gels. F1000Research 2017, 6, 1622. [CrossRef] [PubMed]

7. Arquint, C.; Gabryjonczyk, A.M.; Nigg, E.A. Centrosomes as signalling centres. Philos. Trans. R. Soc. Lond. B Biol. Sci. 2014, 369, 20130464. [CrossRef]

8. Farina, F.; Gaillard, J.; Guerin, C.; Coute, Y.; Sillibourne, J.; Blanchoin, L.; Théry, M. The centrosome is an actin-organizing centre. Nat. Cell Biol. 2016, 18, 65-75. [CrossRef] 
9. Inoue, D.; Obino, D.; Pineau, J.; Farina, F.; Gaillard, J.; Guerin, C.; Blanchoin, L.; Lennon-Dumenil, A.M.; Théry, M. Actin filaments regulate microtubule growth at the centrosome. EMBO J. 2019, 38, e99630. [CrossRef] [PubMed]

10. Oakley, B.R.; Paolillo, V.; Zheng, Y. $\gamma$-Tubulin complexes in microtubule nucleation and beyond. Mol. Biol. Cell 2015, 26, 2957-2962. [CrossRef] [PubMed]

11. Petry, S.; Vale, R.D. Microtubule nucleation at the centrosome and beyond. Nat. Cell Biol. 2015, 17, 1089-1093. [CrossRef] [PubMed]

12. Sulimenko, V.; Hájková, Z.; Klebanovych, A.; Dráber, P. Regulation of microtubule nucleation mediated by $\gamma$-tubulin complexes. Protoplasma 2017, 254, 1187-1199. [CrossRef]

13. Wu, J.; Akhmanova, A. Microtubule-organizing centers. Annu. Rev. Cell Dev. Biol. 2017, 33, 51-75. [CrossRef] [PubMed]

14. Nigg, E.A. Centrosome aberrations: Cause or consequence of cancer progression? Nat. Rev. Cancer 2002, 27, 1554-1561. [CrossRef] [PubMed]

15. Godinho, S.A.; Picone, R.; Burute, M.; Dagher, R.; Su, Y.; Leung, C.T.; Polyak, K.; Brugge, J.S.; Théry, M.; Pellman, D. Oncogene-like induction of cellular invasion from centrosome amplification. Nature 2014, 510, 167-171. [CrossRef] [PubMed]

16. Marteil, G.; Guerrero, A.; Vieira, A.F.; de Almeida, B.P.; Machado, P.; Mendonca, S.; Mesquita, M.; Villarreal, B.; Fonseca, I.; Francia, M.E.; et al. Over-elongation of centrioles in cancer promotes centriole amplification and chromosome missegregation. Nat. Commun. 2018, 9, 1258. [CrossRef]

17. Mittal, K.; Kaur, J.; Jaczko, M.; Wei, G.; Toss, M.S.; Rakha, E.A.; Janssen, E.A.M.; Søiland, H.; Kucuk, O.; Reid, M.D.; et al. Centrosome amplification: A quantifiable cancer cell trait with prognostic value in solid malignancies. Cancer Metastasis Rev. 2021, 40, 319-339. [CrossRef] [PubMed]

18. Goundiam, O.; Basto, R. Centrosomes in disease: How the same music can sound so different? Curr. Opin. Struct. Biol. 2021, 66, 74-82. [CrossRef]

19. Nováková, M.; Dráberová, E.; Schürmann, W.; Czihak, G.; Viklický, V.; Dráber, P. $\gamma$-Tubulin redistribution in taxol-treated mitotic cells probed by monoclonal antibodies. Cell Motil. Cytoskel. 1996, 33, 38-51. [CrossRef]

20. Ludueña, R.F. Are tubulin isotypes functionally significant? Mol. Biol. Cell 1993, 4, 445-457. [CrossRef]

21. Ludueña, R.F. A hypothesis on the origin and evolution of tubulin. Int. Rev. Cell. Mol. Biol. 2013, 302, 41-185. [CrossRef]

22. Roll-Mecak, A. The tubulin code in microtubule dynamics and information encoding. Dev. Cell 2020, 54, 7-20. [CrossRef]

23. Gadadhar, S.; Bodakuntla, S.; Natarajan, K.; Janke, C. The tubulin code at a glance. J. Cell Sci. 2017, 130, 1347-1353. [CrossRef] [PubMed]

24. Janke, C.; Magiera, M.M. The tubulin code and its role in controlling microtubule properties and functions. Nat. Rev. Mol. Cell Biol. 2020, 21, 307-326. [CrossRef] [PubMed]

25. Wolff, A.; Denoulet, P.; Jeantet, C. High level of tubulin microheterogeneity in the mouse brain. Neurosci. Lett. 1982, 31, 323-328. [CrossRef]

26. Linhartová, I.; Dráber, P.; Dráberová, E.; Viklický, V. Immunological discrimination of b-tubulin isoforms in developing mouse brain. Posttranslational modification of non-class III $\beta$-tubulins. Biochem. J. 1992, 288, 919-924. [CrossRef] [PubMed]

27. Bodakuntla, S.; Jijumon, A.S.; Villablanca, C.; Gonzalez-Billault, C.; Janke, C. Microtubule-associated proteins: Structuring the cytoskeleton. Trends Cell Biol. 2019, 29, 804-819. [CrossRef] [PubMed]

28. Portran, D.; Schaedel, L.; Xu, Z.; Thery, M.; Nachury, M.V. Tubulin acetylation protects long-lived microtubules against mechanical ageing. Nat. Cell Biol. 2017, 19, 391-398. [CrossRef] [PubMed]

29. Valenstein, M.L.; Roll-Mecak, A. Graded control of microtubule severing by tubulin glutamylation. Cell 2016, 164, 911-921. [CrossRef]

30. Kavallaris, M. Microtubules and resistance to tubulin-binding agents. Nat. Rev. Cancer 2010, 10, 194-204. [CrossRef]

31. Ludueña, R.F.; Banerjee, A. The isotypes of tubulin: Distribution and functional significance. In The Role of Microtubules in Cell Biology, Neurobiology and Oncology; Fojo, T., Ed.; Humana Press: Totowa, NJ, USA, 2008; pp. 123-175.

32. Kanakkanthara, A.; Miller, J.H. $\beta$ III-tubulin overexpression in cancer: Causes, consequences, and potential therapies. Biochim. Biophys. Acta Rev. Cancer 2021, 1876, 188607. [CrossRef]

33. Kops, G.J.; Weaver, B.A.; Cleveland, D.W. On the road to cancer: Aneuploidy and the mitotic checkpoint. Nat. Rev. Cancer 2005, 5, 773-785. [CrossRef] [PubMed]

34. Katsetos, C.D.; Dráber, P. Tubulins as therapeutic targets in cancer: From bench to bedside. Curr. Pharm. Design 2012, 18, 2778-2792. [CrossRef]

35. Dumontet, C.; Jordan, M.A. Microtubule-binding agents: A dynamic field of cancer therapeutics. Nat. Rev. Drug Discov. 2010, 9, 790-803. [CrossRef] [PubMed]

36. Steinmetz, M.O.; Prota, A.E. Microtubule-targeting agents: Strategies to hijack the cytoskeleton. Trends Cell Biol. 2018, 28 , 776-792. [CrossRef] [PubMed]

37. Mukhtar, E.; Adhami, V.M.; Mukhtar, H. Targeting microtubules by natural agents for cancer therapy. Mol. Cancer Ther. 2014, 13, 275-284. [CrossRef] [PubMed]

38. Parker, A.L.; Teo, W.S.; McCarroll, J.A.; Kavallaris, M. An emerging role for tubulin isotypes in modulating cancer biology and chemotherapy resistance. Int. J. Mol. Sci. 2017, 18, 1434. [CrossRef] [PubMed]

39. Oakley, C.E.; Oakley, B.R. Identification of $\gamma$-tubulin, a new member of the tubulin superfamily encoded by mipA gene of Aspergillus nidulans. Nature 1989, 338, 662-664. [CrossRef] 
40. Stearns, T.; Evans, L.; Kirschner, M. $\gamma$-Tubulin is highly conserved component of the centrosome. Cell 1991, 65, 825-836. [CrossRef]

41. Dráberová, E.; Sulimenko, V.; Vinopal, S.; Sulimenko, T.; Sládková, V.; D’Agostino, L.; Sobol, M.; Hozák, P.; Křen, L.; Katsetos, C.D.; et al. Differential expression of human $\gamma$-tubulin isotypes during neuronal development and oxidative stress points to a $\gamma$-tubulin2 prosurvival function. FASEB J. 2017, 31, 1828-1846. [CrossRef]

42. Ohashi, T.; Yamamoto, T.; Yamanashi, Y.; Ohsugi, M. Human TUBG2 gene is expressed as two splice variant mRNA and involved in cell growth. FEBS Lett. 2016, 590, 1053-1063. [CrossRef]

43. Wise, D.O.; Krahe, R.; Oakley, B.R. The $\gamma$-tubulin gene family in humans. Genomics 2000, 67, 164-170. [CrossRef]

44. Yuba-Kubo, A.; Kubo, A.; Hata, M.; Tsukita, S. Gene knockout analysis of two $\gamma$-tubulin isoforms in mice. Dev. Biol. 2005, 282, 361-373. [CrossRef]

45. Vinopal, S.; Černohorská, M.; Sulimenko, V.; Sulimenko, T.; Vosecká, V.; Flemr, M.; Dráberová, E.; Dráber, P. $\gamma$-Tubulin 2 nucleates microtubules and is downregulated in mouse early embryogenesis. PLoS ONE 2012, 7, e29919. [CrossRef]

46. Gombos, L.; Neuner, A.; Berynskyy, M.; Fava, L.L.; Wade, R.C.; Sachse, C.; Schiebel, E. GTP regulates the microtubule nucleation activity of $\gamma$-tubulin. Nat. Cell Biol. 2013, 15, 1317-1327. [CrossRef] [PubMed]

47. Alvarado-Kristensson, M.; Rodriguez, M.J.; Silio, V.; Valpuesta, J.M.; Carrera, A.C. SADB phosphorylation of $\gamma$-tubulin regulates centrosome duplication. Nat. Cell Biol. 2009, 11, 1081-1092. [CrossRef] [PubMed]

48. Sankaran, S.; Starita, L.M.; Groen, A.C.; Ko, M.J.; Parvin, J.D. Centrosomal microtubule nucleation activity is inhibited by BRCA1-dependent ubiquitination. Mol. Cell Biol. 2005, 25, 8656-8668. [CrossRef]

49. Yin, C.; Lui, E.S.W.; Jiang, T.; Qi, R.Z. Proteolysis of $\gamma$-tubulin small complex proteins is mediated by the ubiquitin-proteasome system. FEBS Lett. 2021, 595, 1987-1996. [CrossRef]

50. Moritz, M.; Braunfeld, M.B.; Sedat, J.W.; Alberts, B.; Agard, D.A. Microtubule nucleation by $\gamma$-tubulin-containing rings in the centrosome. Nature 1995, 378, 638-640. [CrossRef]

51. Zheng, Y.; Alberts, B.; Mitchison, T. Nucleation of microtubule assembly by a $\gamma$-tubulin-containing ring complex. Nature 1995, 378, 578-583. [CrossRef]

52. Kollman, J.M.; Polka, J.K.; Zelter, A.; Davis, T.N.; Agard, D.A. Microtubule nucleating $\gamma$-TuSC assembles structures with 13-fold microtubule-like symmetry. Nature 2010, 466, 879-882. [CrossRef]

53. Kollman, J.M.; Merdes, A.; Mourey, L.; Agard, D.A. Microtubule nucleation by $\gamma$-tubulin complexes. Nat. Rev. Mol. Cell Biol. 2011, 12, 709-721. [CrossRef] [PubMed]

54. Gunawardane, R.N.; Martin, O.C.; Cao, K.; Zhang, L.; Dej, K.; Iwamatsu, A.; Zheng, Y. Characterization and reconstitution of Drosophila $\gamma$-tubulin ring complex subunits. J. Cell Biol. 2000, 151, 1513-1524. [CrossRef]

55. Consolati, T.; Locke, J.; Roostalu, J.; Chen, Z.A.; Gannon, J.; Asthana, J.; Lim, W.M.; Martino, F.; Cvetkovic, M.A.; Rappsilber, J.; et al. Microtubule nucleation properties of single human $\gamma$ TuRCs explained by their cryo-EM structure. Dev. Cell 2020, 53, 603-617. [CrossRef] [PubMed]

56. Liu, P.; Zupa, E.; Neuner, A.; Böhler, A.; Loerke, J.; Flemming, D.; Ruppert, T.; Rudack, T.; Peter, C.; Spahn, C.; et al. Insights into the assembly and activation of the microtubule nucleator $\gamma$-TuRC. Nature 2020, 578, 467-471. [CrossRef] [PubMed]

57. Wieczorek, M.; Urnavicius, L.; Ti, S.C.; Molloy, K.R.; Chait, B.T.; Kapoor, T.M. Asymmetric molecular architecture of the human $\gamma$-tubulin ring complex. Cell 2020, 180, 165-175. [CrossRef]

58. Zimmermann, F.; Serna, M.; Ezquerra, A.; Fernandez-Leiro, R.; Llorca, O.; Lüders, J. Assembly of the asymmetric human $\gamma$-tubulin ring complex by RUVBL1-RUVBL2 AAA ATPase. Sci. Adv. 2020, 6, eabe0894. [CrossRef] [PubMed]

59. Wieczorek, M.; Huang, T.L.; Urnavicius, L.; Hsia, K.C.; Kapoor, T.M. MZT proteins form multi-faceted structural modules in the $\gamma$-tubulin ring complex. Cell Rep. 2020, 31, 107791. [CrossRef]

60. Zupa, E.; Liu, P.; Würtz, M.; Schiebel, E.; Pfeffer, S. The structure of the $\gamma$-TuRC: A 25-years-old molecular puzzle. Curr. Opin. Struct. Biol. 2021, 66, 15-21. [CrossRef]

61. Kollman, J.M.; Greenberg, C.H.; Li, S.; Moritz, M.; Zelter, A.; Fong, K.K.; Fernandez, J.J.; Sali, A.; Kilmartin, J.; Davis, T.N.; et al. Ring closure activates yeast $\gamma$ TuRC for species-specific microtubule nucleation. Nat. Struct. Mol. Biol. 2015, 22, 132-137. [CrossRef]

62. Choi, Y.K.; Liu, P.; Sze, S.K.; Dai, C.; Qi, R.Z. CDK5RAP2 stimulates microtubule nucleation by the $\gamma$-tubulin ring complex. J. Cell Biol. 2010, 191, 1089-1095. [CrossRef]

63. Liu, P.; Choi, Y.K.; Qi, R.Z. NME7 is a functional component of the $\gamma$-tubulin ring complex. Mol. Biol. Cell 2014, 25, 2017-2025. [CrossRef]

64. Wang, Z.; Wu, T.; Shi, L.; Zhang, L.; Zheng, W.; Qu, J.Y.; Niu, R.; Qi, R.Z. Conserved motif of CDK5RAP2 mediates its localization to centrosomes and the Golgi complex. J. Biol. Chem. 2010, 285, 22658-22665. [CrossRef]

65. Lüders, J.; Patel, U.K.; Stearns, T. GCP-WD is a $\gamma$-tubulin targeting factor required for centrosomal and chromatin mediated microtubule nucleation. Nat. Cell Biol. 2006, 8, 137-147. [CrossRef]

66. Zhang, X.; Chen, Q.; Feng, J.; Hou, J.; Yang, F.; Liu, J.; Jiang, Q.; Zhang, C. Sequential phosphorylation of Nedd1 by Cdk1 and Plk1 is required for targeting of the $\gamma$ TuRC to the centrosome. J. Cell Sci. 2009, 122, 2240-2251. [CrossRef]

67. Takahashi, M.; Yamagiwa, A.; Nishimura, T.; Mukai, H.; Ono, Y. Centrosomal proteins CG-NAP and kendrin provide microtubule nucleation sites by anchoring $\gamma$-tubulin ring complex. Mol. Biol. Cell 2002, 13, 3235-3245. [CrossRef]

68. Zimmerman, W.C.; Sillibourne, J.; Rosa, J.; Doxsey, S.J. Mitosis-specific anchoring of $\gamma$-tubulin complexes by pericentrin controls spindle organization and mitotic entry. Mol. Biol. Cell 2004, 15, 3642-3657. [CrossRef] [PubMed] 
69. Delgehyr, N.; Sillibourne, J.; Bornens, M. Microtubule nucleation and anchoring at the centrosome are independent processes linked by ninein function. J. Cell Sci. 2005, 118, 1565-1575. [CrossRef] [PubMed]

70. Gomez-Ferreria, M.A.; Rath, U.; Buster, D.W.; Chanda, S.K.; Caldwell, J.S.; Rines, D.R.; Sharp, D.J. Human Cep192 is required for mitotic centrosome and spindle assembly. Curr. Biol. 2007, 17, 1960-1966. [CrossRef] [PubMed]

71. Singh, P.; Thomas, G.E.; Gireesh, K.K.; Manna, T.K. TACC3 protein regulates microtubule nucleation by affecting $\gamma$-tubulin ring complexes. J. Biol. Chem. 2014, 289, 31719-31735. [CrossRef] [PubMed]

72. Rajeev, R.; Singh, P.; Asmita, A.; Anand, U.; Manna, T.K. Aurora A site specific TACC3 phosphorylation regulates astral microtubule assembly by stabilizing $\gamma$-tubulin ring complex. BMC Mol. Cell Biol. 2019, 20, 58. [CrossRef]

73. Tovey, C.A.; Tubman, C.E.; Hamrud, E.; Zhu, Z.; Dyas, A.E.; Butterfield, A.N.; Fyfe, A.; Johnson, E.; Conduit, P.T. $\gamma$-TuRC heterogeneity revealed by analysis of Mozart1. Curr. Biol. 2018, 28, 2314-2323. [CrossRef] [PubMed]

74. Schweizer, N.; Lüders, J. From tip to toe-dressing centrioles in $\gamma$ TuRC. J. Cell Sci. 2021, 134, jcs258397. [CrossRef] [PubMed]

75. Bouissou, A.; Verollet, C.; Sousa, A.; Sampaio, P.; Wright, M.; Sunkel, C.E.; Merdes, A.; Raynaud-Messina, B. $\gamma$-Tubulin ring complexes regulate microtubule plus end dynamics. J. Cell Biol. 2009, 187, 327-334. [CrossRef]

76. Hendrickson, T.W.; Yao, J.; Bhadury, S.; Corbett, A.H.; Joshi, H.C. Conditional mutations in $\gamma$-tubulin reveal its involvement in chromosome segregation and cytokinesis. Mol. Biol. Cell 2001, 12, 2469-2481. [CrossRef]

77. Nayak, T.; Edgerton-Morgan, H.; Horio, T.; Xiong, Y.; De Souza, C.P.; Osmani, S.A.; Oakley, B.R. $\gamma$-Tubulin regulates the anaphase-promoting complex/cyclosome during interphase. J. Cell Biol. 2010, 190, 317-330. [CrossRef]

78. Hořejší, B.; Vinopal, S.; Sládková, V.; Dráberová, E.; Sulimenko, V.; Sulimenko, T.; Vosecká, V.; Philimonenko, A.; Hozák, P.; Katsetos, C.D.; et al. Nuclear $\gamma$-tubulin associates with nucleoli and interacts with tumor suppressor protein C53. J. Cell. Physiol. 2012, 227, 367-382. [CrossRef]

79. Höög, G.; Zarrizi, R.; von Stedingk, K.; Jonsson, K.; Alvarado-Kristensson, M. Nuclear localization of $\gamma$-tubulin affects E2F transcriptional activity and S-phase progression. FASEB J. 2011, 25, 3815-3827. [CrossRef] [PubMed]

80. Kállai, B.M.; Kourová, H.; Chumová, J.; Papdi, C.; Trögelová, L.; Kofroňová, O.; Hozák, P.; Filimonenko, V.; Mészáros, T.; Magyar, Z.; et al. $\gamma$-Tubulin interacts with E2F transcription factors to regulate proliferation and endocycling in Arabidopsis. J. Exp. Bot. 2020, 71, 1265-1277. [CrossRef] [PubMed]

81. Lesca, C.; Germanier, M.; Raynaud-Messina, B.; Pichereaux, C.; Etievant, C.; Emond, S.; Burlet-Schiltz, O.; Monsarrat, B.; Wright, M.; Defais, M. DNA damage induce $\gamma$-tubulin-RAD51 nuclear complexes in mammalian cells. Oncogene 2005, 24, 5165-5172. [CrossRef]

82. Hubert, T.; Vandekerckhove, J.; Gettemans, J. Cdk1 and BRCA1 target $\gamma$-tubulin to microtubule domains. Biochem. Biophys. Res. Commun. 2011, 414, 240-245. [CrossRef]

83. Zhang, S.; Hernmerich, P.; Grosse, F. Centrosomal localization of DNA damage checkpoint proteins. J. Cell. Biochem. 2007, 101, 451-465. [CrossRef]

84. Sulimenko, V.; Sulimenko, T.; Poznanovic, S.; Nechiporuk-Zloy, V.; Böhm, J.K.; Macurek, L.; Unger, E.; Dráber, P. Association of brain $\gamma$-tubulins with $\alpha \beta$-tubulin dimers. Biochem. J. 2002, 365, 889-895. [CrossRef] [PubMed]

85. Chumová, J.; Trögelová, L.; Kourová, H.; Volc, J.; Sulimenko, V.; Halada, P.; Kučera, O.; Benada, O.; Kuchařová, A.; Klebanovych, A.; et al. $\gamma$-Tubulin has a conserved intrinsic property of self-polymerization into double stranded filaments and fibrillar networks. BBA Mol. Cell Res. 2018, 1865, 734-748. [CrossRef]

86. Lindström, L.; Li, T.; Malycheva, D.; Kancharla, A.; Nilsson, H.; Vishnu, N.; Mulder, H.; Johansson, M.; Rosselló, C.A.; AlvaradoKristensson, M. The GTPase domain of gamma-tubulin is required for normal mitochondrial function and spatial organization. Commun. Biol. 2018, 1, 37. [CrossRef] [PubMed]

87. Chumová, J.; Kourová, H.; Trögelová, L.; Halada, P.; Binarová, P. Microtubular and nuclear functions of $\gamma$-tubulin: Are they LINCed? Cells 2019, 8, 259. [CrossRef]

88. Rosselló, C.A.; Lindström, L.; Eklund, G.; Corvaisier, M.; Alvarado-Kristensson, M.A. $\gamma$-Tubulin- $\gamma$-tubulin interactions as the basis for the formation of a meshwork. Int. J. Mol. Sci. 2018, 19, 3245. [CrossRef] [PubMed]

89. Chabin-Brion, K.; Marceiller, J.; Perez, F.; Settegrana, C.; Drechou, A.; Durand, G.; Pous, C. The Golgi complex is a microtubuleorganizing organelle. Mol. Biol. Cell 2001, 12, 2047-2060. [CrossRef]

90. Hehnly, H.; Doxsey, S. Rab11 endosomes contribute to mitotic spindle organization and orientation. Dev. Cell 2014, 28, 497-507. [CrossRef]

91. Katsetos, C.D.; Dráberová, E.; Legido, A.; Dráber, P. Tubulin targets in the pathobiology and therapy of glioblastoma multiforme. II. g-Tubulin. J. Cell. Physiol. 2009, 221, 514-520. [CrossRef]

92. Ohgaki, H.; Kleihues, P. Population-based studies on incidence, survival rates, and genetic alterations in astrocytic and oligodendroglial gliomas. J. Neuropathol. Exp. Neurol. 2005, 64, 479-489. [CrossRef]

93. Rickman, D.S.; Bobek, M.P.; Misek, D.E.; Kuick, R.; Blaivas, M.; Kurnit, D.M.; Taylor, J.; Hanash, S.M. Distinctive molecular profiles of high-grade and low-grade gliomas based on oligonucleotide microarray analysis. Cancer Res. 2001, 61, 6885-6891. [PubMed]

94. Katsetos, C.D.; Reddy, G.; Dráberová, E.; Šmejkalová, B.; Del Valle, L.; Ashraf, Q.; Tradevosyan, A.; Yelin, K.; Maraziotis, T.; Mishra, O.P.; et al. Altered cellular distribution and subcellular sorting of $\gamma$-tubulin in diffuse astrocytic gliomas and human glioblastoma cell lines. J. Neuropathol. Exp. Neurol. 2006, 65, 465-477. [CrossRef] [PubMed] 
95. Katsetos, C.D.; Dráberová, E.; Šmejkalová, B.; Reddy, G.; Bertrand, L.; de Chadarévian, J.P.; Legido, A.; Nissanov, J.; Baas, P.W.; Dráber, P. Class III $\beta$-tubulin and $\gamma$-tubulin are co-expressed and form complexes in human glioblastoma cells. Neurochem. Res. 2007, 32, 1387-1398. [CrossRef]

96. Loh, J.K.; Lieu, A.S.; Chou, C.H.; Lin, F.Y.; Wu, C.H.; Howng, S.L.; Chio, C.C.; Hong, Y.R. Differential expression of centrosomal proteins at different stages of human glioma. BMC Cancer 2010, 10, 268. [CrossRef]

97. Loh, J.K.; Lieu, A.S.; Chou, C.H.; Lin, C.C.; Yang, M.C.; Lin, F.Y.; Hong, Y.R.; Howng, S.L. Differential expression of centrosomeassociated proteins in human brain tumors: A possible role of hNinein isoform 6 in cell differentiation. Biofactors 2012, 38, 470-477. [CrossRef] [PubMed]

98. Tsai, H.P.; Tsai, C.Y.; Lieu, A.S.; Chai, C.Y.; Kwan, A.L.; Howng, S.L.; Loh, J.K. Association of Aurora A and $\gamma$-tubulin expression in astrocytomas and patient survival. Neurol. Res. 2014, 36, 746-751. [CrossRef]

99. Caracciolo, V.; D’Agostino, L.; Dráberová, E.; Sládková, V.; Crozier-Fitzgerald, C.; Agamanolis, D.P.; de Chadarévian, J.P.; Legido, A.; Giordano, A.; Dráber, P.; et al. Differential expression and cellular distribution of $\gamma$-tubulin and $\beta$ III-tubulin in medulloblastomas and human medulloblastoma cell lines. J. Cell. Physiol. 2010, 223, 519-529. [CrossRef]

100. Harbeck, N.; Penault-Llorca, F.; Cortes, J.; Gnant, M.; Houssami, N.; Poortmans, P.; Ruddy, K.; Tsang, J.; Cardoso, F. Breast cancer. Nat. Rev. Dis. Primers 2019, 5, 66. [CrossRef]

101. Liu, T.; Niu, Y.; Yu, Y.; Liu, Y.; Zhang, F. Increased $\gamma$-tubulin expression and P16 ${ }^{\mathrm{INK} 4 \mathrm{~A}}$ promoter methylation occur together in preinvasive lesions and carcinomas of the breast. Ann. Oncol. 2009, 20, 441-448. [CrossRef]

102. Niu, Y.; Liu, T.; Tse, G.M.; Sun, B.; Niu, R.; Li, H.M.; Wang, H.; Yang, Y.; Ye, X.; Wang, Y.; et al. Increased expression of centrosomal $\alpha, \gamma$-tubulin in atypical ductal hyperplasia and carcinoma of the breast. Cancer Sci. 2009, 100, 580-587. [CrossRef]

103. Cho, E.H.; Whipple, R.A.; Matrone, M.A.; Balzer, E.M.; Martin, S.S. Delocalization of $\gamma$-tubulin due to increased solubility in human breast cancer cell lines. Cancer Biol. Ther. 2010, 9, 66-76. [CrossRef] [PubMed]

104. Sankaran, S.; Crone, D.E.; Palazzo, R.E.; Parvin, J.D. BRCA1 regulates $\gamma$-tubulin binding to centrosomes. Cancer Biol. Ther. 2007, 6, 1853-1857. [CrossRef] [PubMed]

105. Yoshino, Y.; Fang, Z.; Qi, H.; Kobayashi, A.; Chiba, N. Dysregulation of the centrosome induced by BRCA1 deficiency contributes to tissue-specific carcinogenesis. Cancer Sci. 2021, 112, 1679-1687. [CrossRef] [PubMed]

106. Zarrizi, R.; Menard, J.A.; Belting, M.; Massoumi, R. Deubiquitination of $\gamma$-tubulin by BAP1 prevents chromosome instability in breast cancer cells. Cancer Res. 2014, 74, 6499-6508. [CrossRef] [PubMed]

107. Maounis, N.F.; Dráberová, E.; Mahera, E.; Chorti, M.; Caracciolo, V.; Sulimenko, T.; Riga, D.; Trakas, N.; Emmanouilidou, A.; Giordano, A.; et al. Overexpression of $\gamma$-tubulin in non-small cell lung cancer. Histol. Histopathol. 2012, 27, 1183-1194. [CrossRef]

108. Maounis, N.F.; Dráberová, E.; Trakas, N.; Chorti, M.; Riga, D.; Tzannis, K.; Kanakis, M.; Voralu, K.; Ellina, E.; Mahera, E.; et al. Expression of $\gamma$-tubulin in non-small cell lung cancer and effect on patient survival. Histol. Histopathol. 2019, 34, 81-90. [CrossRef] [PubMed]

109. Syed, M.I.; Syed, S.; Minty, F.; Harrower, S.; Singh, J.; Chin, A.; McLellan, D.R.; Parkinson, E.K.; Clark, L.J. Gamma tubulin: A promising indicator of recurrence in squamous cell carcinoma of the larynx. Otolaryngol. Head Neck Surg. 2009, 140, 498-504. [CrossRef]

110. Montero-Conde, C.; Martin-Camposo, J.M.; Lerma, E.; Martinez-Guitarte, J.L.; Combalia, N.; Montaner, D.; Matias-Guiu, X.; Dopazo, J.; de Leiva, A.; Robledo, M.; et al. Molecular profiling related to poor prognosis in thyroid carcinoma. Combining gene expression data and biological information. Oncogene 2008, 27, 1554-1561. [CrossRef]

111. Hsu, L.C.; Kapali, M.; DeLoia, J.A.; Gallion, H.H. Centrosome abnormalities in ovarian cancer. Int. J. Cancer 2005, 113, 746-751. [CrossRef]

112. Li, Y.W.; Hussain, M.; Sarkar, S.H.; Eliason, J.; Li, R.; Sarkar, F.H. Gene expression profiling revealed novel mechanism of action of Taxotere and Furtulon in prostate cancer cells. BMC Cancer 2005, 5, 7. [CrossRef]

113. LoMastro, G.M.; Holland, A.J. The emerging link between centrosome aberrations and metastasis. Dev. Cell 2019, 49, 325-331. [CrossRef]

114. Dráberová, E.; D’Agostino, L.; Caracciolo, V.; Sládková, V.; Sulimenko, T.; Sulimenko, V.; Sobol, M.; Maounis, N.F.; Tzelepis, E.; Mahera, E.; et al. Overexpression and nucleolar localization of $\gamma$-tubulin small complex proteins GCP2 and GCP3 in glioblastoma. J. Neuropathol. Exp. Neurol. 2015, 74, 723-742. [CrossRef]

115. Huang, S.L.; Chao, C.C. Silencing of taxol-sensitizer genes in cancer cells: Lack of sensitization effects. Cancers 2015, 7, $1052-1071$. [CrossRef]

116. Wang, H.; Jiang, X.; Cheng, Y.; Ren, H.; Hu, Y.; Zhang, Y.; Su, H.; Zou, Z.; Wang, Q.; Liu, Z.; et al. MZT2A promotes NSCLC viability and invasion by increasing Akt phosphorylation via the MOZART2 domain. Cancer Sci. 2021, 112, 2210-2222. [CrossRef]

117. Liu, P.; Würtz, M.; Zupa, E.; Pfeffer, S.; Schiebel, E. Microtubule nucleation: The waltz between $\gamma$-tubulin ring complex and associated proteins. Curr. Opin. Cell Biol. 2021, 68, 124-131. [CrossRef] [PubMed]

118. Suresh, R.; Diaz, R.J. The remodelling of actin composition as a hallmark of cancer. Transl. Oncol. 2021, 14, 101051. [CrossRef] [PubMed]

119. Po'uha, S.T.; Kavallaris, M. Gamma-actin is involved in regulating centrosome function and mitotic progression in cancer cells. Cell Cycle 2015, 14, 3908-3919. [CrossRef] [PubMed]

120. Nejedlá, M.; Sadi, S.; Sulimenko, V.; de Almeida, F.N.; Blom, H.; Dráber, P.; Aspenström, P.; Karlsson, R. Profilin connects actin assembly with microtubule dynamics. Mol. Biol. Cell 2016, 27, 2381-2393. [CrossRef] 
121. Henty-Ridilla, J.L.; Juanes, M.A.; Goode, B.L. Profilin directly promotes microtubule growth through residues mutated in amyotrophic lateral sclerosis. Curr. Biol. 2017, 27, 3535-3543. [CrossRef] [PubMed]

122. Nejedlá, M.; Klebanovych, A.; Sulimenko, V.; Sulimenko, T.; Dráberová, E.; Dráber, P.; Karlsson, R. The actin regulator profilin 1 is functionally associated with the mammalian centrosome. Life Sci. Alliance 2021, 4, e202000655. [CrossRef]

123. Pimm, M.L.; Hotaling, J.; Henty-Ridilla, J.L. Profilin choreographs actin and microtubules in cells and cancer. Int. Rev. Cell Mol. Biol. 2020, 355, 155-204. [CrossRef]

124. Karlsson, R.; Dráber, P. Profilin-A master coordinator of actin and microtubule organization in mammalian cells. J. Cell. Physiol. 2021, 236, 7256-7265. [CrossRef] [PubMed]

125. Khodjakov, A.; Rieder, C.L. The sudden recruitment of $\gamma$-tubulin to the centrosome at the onset of mitosis and its dynamic exchange throughout the cell cycle, do not require microtubules. J. Cell Biol. 1999, 146, 585-596. [CrossRef] [PubMed]

126. Yao, R.; Kondoh, Y.; Natsume, Y.; Yamanaka, H.; Inoue, M.; Toki, H.; Takagi, R.; Shimizu, T.; Yamori, T.; Osada, H.; et al. A small compound targeting TACC3 revealed its different spatiotemporal contributions for spindle assembly in cancer cells. Oncogene 2014, 33, 4242-4252. [CrossRef] [PubMed]

127. Sabat-Pospiech, D.; Fabian-Kolpanowicz, K.; Prior, I.A.; Coulson, J.M.; Fielding, A.B. Targeting centrosome amplification, an Achilles' heel of cancer. Biochem. Soc. Trans. 2019, 47, 1209-1222. [CrossRef] [PubMed]

128. Friesen, D.E.; Barakat, K.H.; Semenchenko, V.; Perez-Pineiro, R.; Fenske, B.W.; Mane, J.; Wishart, D.S.; Tuszynski, J.A. Discovery of small molecule inhibitors that interact with $\gamma$-tubulin. Chem. Biol. Drug. Des. 2012, 79, 639-652. [CrossRef] [PubMed]

129. Aldaz, H.; Rice, L.M.; Stearns, T.; Agard, D.A. Insights into microtubule nucleation from the crystal structure of human $\gamma$-tubulin. Nature 2005, 435, 523-527. [CrossRef] [PubMed]

130. Chinen, T.; Liu, P.; Shioda, S.; Pagel, J.; Cerikan, B.; Lin, T.C.; Gruss, O.; Hayashi, Y.; Takeno, H.; Shima, T.; et al. The $\gamma$-tubulinspecific inhibitor gatastatin reveals temporal requirements of microtubule nucleation during the cell cycle. Nat. Commun. 2015, 6, 8722. [CrossRef]

131. Rayevsky, A.S.M.; Samofalova, D.; Demchuk, O.; Karpov, P.; Blume, Y. In silico mechanistic model of microtubule assembly inhibition by selective chromone derivatives. J. Mol. Struct. 2021, 1241, 130633. [CrossRef]

132. Ebisu, H.; Shintani, K.; Chinen, T.; Nagumo, Y.; Shioda, S.; Hatanaka, T.; Sakakura, A.; Hayakawa, I.; Kigoshi, H.; Usui, T. Dual inhibition of $\gamma$-tubulin and Plk1 induces mitotic cell death. Front. Pharmacol. 2020, 11, 620185. [CrossRef] [PubMed]

133. Shintani, K.; Ebisu, H.; Mukaiyama, M.; Hatanaka, T.; Chinen, T.; Takao, D.; Nagumo, Y.; Sakakura, A.; Hayakawa, I.; Usui, T. Structure optimization of gatastatin for the development of $\gamma$-tubulin-specific inhibitor. ACS Med. Chem. Lett. 2020, 11, 1125-1129. [CrossRef]

134. Traversi, G.; Staid, D.S.; Fiore, M.; Percario, Z.; Trisciuoglio, D.; Antonioletti, R.; Morea, V.; Degrassi, F.; Cozzi, R. A novel resveratrol derivative induces mitotic arrest, centrosome fragmentation and cancer cell death by inhibiting $\gamma$-tubulin. Cell Div. 2019, 14, 3. [CrossRef]

135. Naik, P.K.; Santoshi, S.; Rai, A.; Joshi, H.C. Molecular modelling and competition binding study of Br-noscapine and colchicine provide insight into noscapinoid-tubulin binding site. J. Mol. Graph. Model. 2011, 29, 947-955. [CrossRef] [PubMed]

136. Suri, C.; Naik, P.K. Combined molecular dynamics and continuum solvent approaches (MM-PBSA/GBSA) to predict noscapinoid binding to gamma-tubulin dimer. SAR QSAR Environ. Res. 2015, 26, 507-519. [CrossRef] [PubMed]

137. Altinoz, M.A.; Topcu, G.; Hacimuftuoglu, A.; Ozpinar, A.; Ozpinar, A.; Hacker, E.; Elmaci, I. Noscapine, a non-addictive opioid and microtubule-inhibitor in potential treatment of glioblastoma. Neurochem. Res. 2019, 44, 1796-1806. [CrossRef] [PubMed]

138. Knudsen, E.S.; Nambiar, R.; Rosario, S.R.; Smiraglia, D.J.; Goodrich, D.W.; Witkiewicz, A.K. Pan-cancer molecular analysis of the RB tumor suppressor pathway. Commun. Biol. 2020, 3, 158. [CrossRef] [PubMed]

139. Ehlén, Å.; Rosselló, C.A.; von Stedingk, K.; Höög, G.; Nilsson, E.; Pettersson, H.M.; Jirström, K.; Alvarado-Kristensson, M. Tumors with nonfunctional retinoblastoma protein are killed by reduced $\gamma$-tubulin levels. J. Biol. Chem. 2012, 287, 17241-17247. [CrossRef]

140. Lindström, L.; Villoutreix, B.O.; Lehn, S.; Hellsten, R.; Nilsson, E.; Crneta, E.; Olsson, R.; Alvarado-Kristensson, M. Therapeutic targeting of nuclear $\gamma$-tubulin in RB1-negative tumors. Mol. Cancer Res. 2015, 13, 1073-1082. [CrossRef] 